\title{
Chlamydia-like organisms in ctenidia and mantle cells of the Japanese oyster Crassostrea gigas from the French Atlantic coast
}

\author{
T. Renault*, N. Cochennec \\ IFREMER, Laboratoire de Biologie et d'Ecologie des Invertébrés Marins, Unité de Recherche en Pathologie et Immunologie \\ Générales, BP 133, F-17390 La Tremblade, France
}

\begin{abstract}
Grossly visible lesions of the ctenidia and occasional mortalities in Japanese oyster Crassostrea gigas from the Atlantic French coast were reported in 1992-1993. From August 1992 to March 1993, 235 living oysters were collected to determine the cause of tissue lesions and mortalities. Microscopical examination of fixed, stained sections revealed that $53.2 \%$ of these oysters had ctenidia and mantle lesions associated with irregular basophilic and Feulgen positive cytoplasmic inclusion bodies. Ultrastructurally, the infectious agent was a chlamydia-like organism. Indirect fluorescent and peroxidase conjugated antibody tests suggested that this agent might share common antigens with the procaryotic agent Chlamydia psittaci, strain ovis

KEY WORDS: Crassostrea gigas - Pacific oyster - Chlamydia-like organisms - Ctenidia - Mantle
\end{abstract}

\section{INTRODUCTION}

Various rickettsial and chlamydial agents occur in many species of bivalve molluscs (Comps et al. 1977a, b, Harshbarger et al. 1977, Buchanan 1978, Comps \& Deltreil 1979, Meyers 1979, Joly \& Comps 1980, Morrison \& Shum 1982, 1983, Gulka et al. 1983, Elston \& Peacock 1984, Couch 1985, Elston 1986, Le Gall et al. 1988, Azevedo \& Villalba 1991, Cajaraville \& Angulo 1991, Fries et al. 1991, Norton et al. 1993). Although these procaryotic organisms parasitize many different species of bivalve molluscs, only a few are described as pathogens associated with lesions or mortalities of adult cultured bivalves (Buchanan 1978, Gulka et al. 1983, Elston \& Peacock 1984, Elston 1986, Le Gall et al. 1988, Norton et al. 1993). In hatchery-reared larval and post-metamorphic Argopecten irradians, chlamydiosis is apparently an extremely lethal epizootic disease, but it is enzootic in adults (Leibovitz 1989).

The present study reports, for the first time, macroscopic ctenidia lesions and occasional mortalities of the

•E-mail: trenault@ifremer.fr
Japanese oyster Crassostrea gigas collected from the French Atlantic coast in 1992-1993, associated with the detection of a chlamydia-like organism in connective tissues of ctenidia and mantle.

\section{MATERIALS AND METHODS}

Source of specimens. Cultured Japanese oysters Crassostrea gigas were collected and examined from August 1992 to March 1993 at 4 locations (Ronce les Bains, Bourcefranc le Chapus, Fouras and Arcachon) along the south Atlantic coast of France. A total of 235 adult oysters ( 1 to 3 yr old) was examined. Oysters from Brittany, Normandy and the Mediterranean Sea were also analysed.

Light microscopy. After oysters were removed from the shell, they were sagittally sectioned, then half was placed in Davidson's fixative, and the other half in Carson's fixative. Samples fixed in Davidson's fluid were dehydrated using an ascending ethanol series, cleared in xylene and infiltrated with paraffin. They were then embedded in paraffin, sectioned at 3 or $4 \mu \mathrm{m}$ thickness, stained with hematoxylin and eosin and 
carefully checked for lesions. Macchiavello's method for microorganisms belonging to the genus Rickettsia (Culling 1974), the acridine orange stain for psittacosis agent (Starr et al. 1960) and the nucleal Feulgen and Rossenbeck reaction for DNA detection were also used on selected slides. Samples placed in Carson's fixative were held for electron microscopy.

Electron microscopy. Ctenidia and mantle tissues were collected from live oysters or from those previously placed in Carson's fixative, then fixed in $2.5 \%$ glutaraldehyde in $0.2 \mathrm{M}$ cacodylate buffer at a $\mathrm{pH}$ of 7.4 and post-fixed in $1 \%$ osmium tetroxide in the same buffer for $1 \mathrm{~h}$ at $4^{\circ} \mathrm{C}$. After dehydration by means of an ascending ethanol series, specimens were cleared in propylene oxide and embedded in Epon resin. Semithin sections for light microscopy were stained in $0.5 \%$ toluidine blue in $1 \%$ sodium borate solution. Ultrathin sections were collected on uncoated copper grids, double stained with uranyl acetate and lead citrate, and observed in a JEOL JEM 1200 EX transmission electron microscope at $60 \mathrm{kV}$.

Indirect immunofluorescence and immunoperoxidase. Five pretitered anti-Chlamydia psittaci, strain ovis monoclonal antibodies and sheep anti-chlamydial serum (kindly provided by Dr A. Rodolakis, Institut National de la Recherche Agronomique, Laboratoire de Pathologie Infectieuse et Immunologie, Nouzilly, France), having a complement fixation titer of 1:2000 against C. psittaci, strain ovis, which causes sheep abortions, were used for indirect testing with pretitered, fluorescein isothiocyanate or peroxidase conjugated goat anti-mouse (Institut Pasteur) and donkey anti-sheep immunoglobulins (Sigma). Tissue sections from samples fixed in Carson's and Davidson's fixatives were cut at 3 or $4 \mu \mathrm{m}$ thickness. After dewaxing and hydration, they were overlaid with a solution of $3 \%(\mathrm{w} / \mathrm{v})$ powdered milk in phosphate-buffered saline (PBS, pH 7.4) for $30 \mathrm{~min}$, to block nonspecific binding sites. After this first step, the histological slides were again overlaid with monoclonal antibodies or antichlamydial serum diluted from 1:100 to 1:10000 in PBS with supplemented $0.5 \%$ milk powder. After a $45 \mathrm{~min}$ incubation at $37^{\circ} \mathrm{C}$ in a moist chamber, tissue sections were washed with PBS and then overlaid with fluorescein isothiocyanate or peroxidase conjugated goat anti-mouse or donkey anti-sheep diluted in PBS supplemented with $0.01 \%$ Evans blue for indirect immunofluorescence. Slides were again incubated in a moist chamber for $1 \mathrm{~h}$ and then washed in the same buffer. They were examined for light green fluorescent or brown-stained intracellular procaryotic agents. For the peroxidase assays, an inhibition of endogenous peroxidase activities was performed with a methanol bath supplemented with $0.3 \%$ hydrogen peroxide for $30 \mathrm{~min}$.

The specificity of indirect tests was monitored by processing known Chlamydia psittaci, strain ovis positive controls in parallel with the oyster sections. These controls were performed on McCoy cell cultures infected by C. psittaci, strain ovis and fixed in acetone. Uninfected cell cultures were also included as negative controls. Sections of uninfected Japanese oysters originating from Brittany (Etel), Normandy (Gouville) and the Mediterranean Sea (Etang de Thau) and healthy European flat oysters Ostreae edulis from Brittany (La Trinité) were used as negative controls.

An antibody negative control consisting of antiBonamia ostreae monoclonal antibodies was tested on infected Japanese oysters sections.

\section{RESULTS}

\section{Gross appearance and prevalence of ctenidia lesions}

Ctenidia lesions appeared as indentations in lamellae (Fig. 1). Most affected oysters showed one to several indentations. When the infection was heavy, the whole lamella was affected and very reduced in size.

We only recorded mortality levels $(30 \%)$ for 2 yr old Japanese oysters originating from Ronce les Bains, collected in August 1992 and December 1993.

\section{Histopathology of ctenidia and mantle lesions}

Paraffin sections of affected oysters stained with hematoxylin and eosin showed irregular cytoplasmic inclusion bodies in connective tissue cells of ctenidia and mantle (Fig. 2). These inclusions were very basophilic and

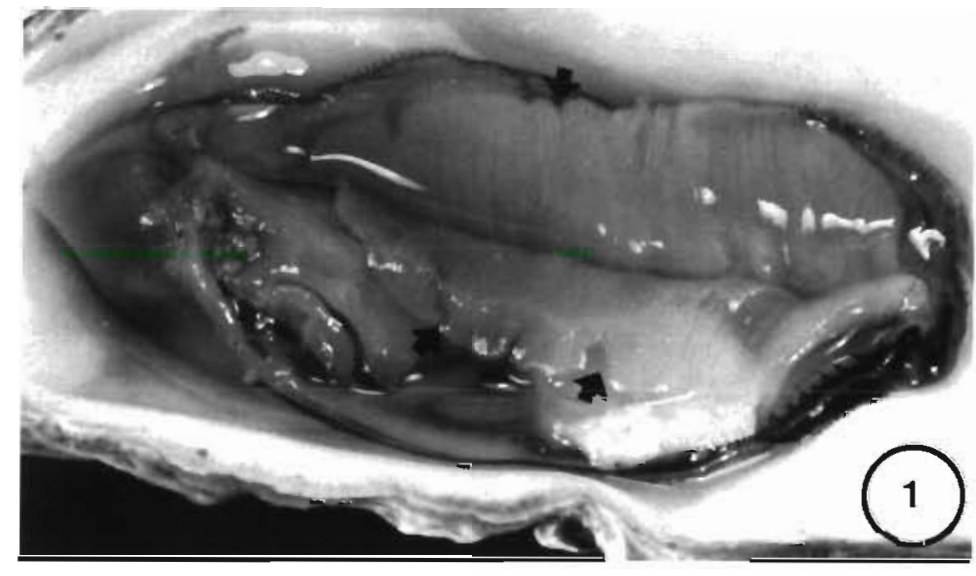

Fig. 1. Crassostrea gigas. Pacific oyster with marginal indentations (arrows) in the ctenidia lamellae 


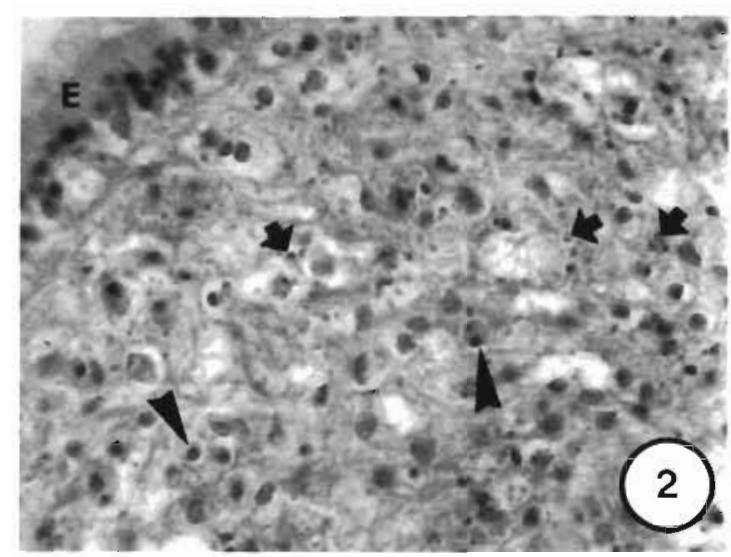

Fig. 2. Crassostrea gigas. Light micrograph of mantle tissues. Irregular basophilic and intracytoplasmic inclusions (arrows) and pyknotic nuclei (arrowheads) are seen in mantle connective tissues. In this zone, mantle epithelium (E) is normal. Hematoxylin and eosin. $\times 800$

varied in size and distribution, but were never very large. They did not stain positively with the modified Macchiavello's stain for rickettsias, but were Feulgen positive. No result was obtained on infected oyster sections with acridine orange stain and ultraviolet illumination. When the infection was heavy, hemocytic cellular infiltration and cell necrosis of gill and mantle connective tissues were visible and extensive. Nuclei in infected connective tissues gradually became pycnotic (Fig. 2), and the cytoplasm became disintegrated. Cell necrosis of gill and mantle epithelia was also seen.

The proportions of infected oysters in the different sampling groups from the French Atlantic coast varied from 30 to $66.6 \%$ and are reported in Table 1. Among the 235 oysters examined, 125 were found infected (prevalence $53.2 \%$ ).

No abnormality was detected in oysters originating from Brittany, Normandy or the Mediterranean Sea.

Table 1. Crassostrea gigas. Prevalence of abnormalities $(P)$ in samples examined by histology (August 1992 to March 1993). $S$ : sample size

\begin{tabular}{|lcrc|}
\hline Origin of samples & Date & $S$ & $P$ \\
\hline Ronce & Aug 1992 & 12 & $41.5 \%$ \\
Ronce & Dec 1992 & 6 & $66.6 \%$ \\
Fouras & Feb 1993 & 30 & $36.6 \%$ \\
Arcachon & Mar 1993 & 30 & $30.0 \%$ \\
Arcachon & Mar 1993 & 28 & $53.5 \%$ \\
Ronce & Mar 1993 & 30 & $66.6 \%$ \\
Le Chapus & Mar 1993 & 99 & $61.6 \%$ \\
Etel & Mar 1993 & 50 & $0 \%$ \\
Gouville & Mar 1993 & 50 & $0 \%$ \\
Etang de Thau & Mar 1993 & 50 & $0 \%$ \\
Total & & 385 & \\
& & & \\
\hline
\end{tabular}

\section{Ultrastructure of infected oysters}

Semithin sections of Japanese oysters revealed inclusion bodies staining deep blue in cells of ctenidia and mantle connective tissues. In addition, hypertrophied cells, up to $25 \mu \mathrm{m}$ in size, with cytoplasmic inclusions or a granular cytoplasm were observed in affected areas (Fig. 3).

Thin sections of ctenidia and mantle tissue samples from 13 infected Japanese oysters were observed by transmission electron microscopy. All contained different stages of a procaryotic organism in the cytoplasm of connective tissue cells. Reticulate bodies, intermediate condensing forms and elementary bodies were clearly distinguished. The earliest noted alteration of ctenidia and mantle connective tissue was the presence of individual intracytoplasmic vacuoles containing some elementary bodies, intermediate forms and reticulate bodies (Fig. 4). As the developing intermediate bodies increased in size, they became less electron dense. These intermediate bodies became further enlarged, vacuolated and transformed into pleomorphic reticulate bodies. The reticulate bodies had a clear central area, containing fine filaments, and were peripherally filled with electron dense material (Fig. 5). The shape of the reticulate bodies, although pleomorphic, tended to be irregularly round or oval, and they measured approximately $500 \mathrm{~nm}$ to $1.5 \mu \mathrm{m}$ in diameter (Fig. 5). Intermediate bodies were also pleomorphic with a size of approximately 300 to $500 \mathrm{~nm}$ (Figs. 6a, b). Both types of body were double membrane bound or exhibited a pentalaminar structure (Figs. 5 \& 6). The double membrane was best observed in samples directly fixed in glutaraldehyde (Fig. 5). Mature elementary bodies were oval to fusiform in shape and ranged in size from 80 to

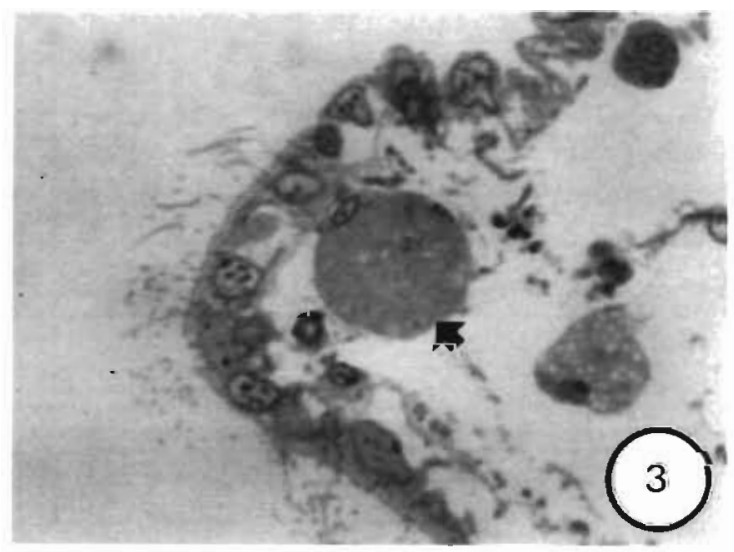

Fig. 3. Crassostrea gigas. Semithin section stained with toluidine blue. Hypertrophied cells (arrow) with cytoplasmic inclusions or a granular cytoplasm are observed in connective tissues of gills. $\times 800$ 


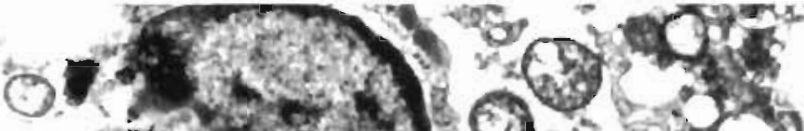

2710 610.

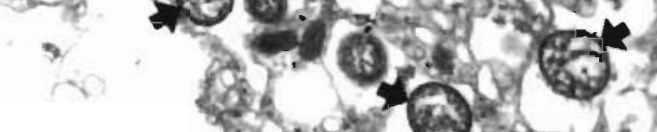
10.6.
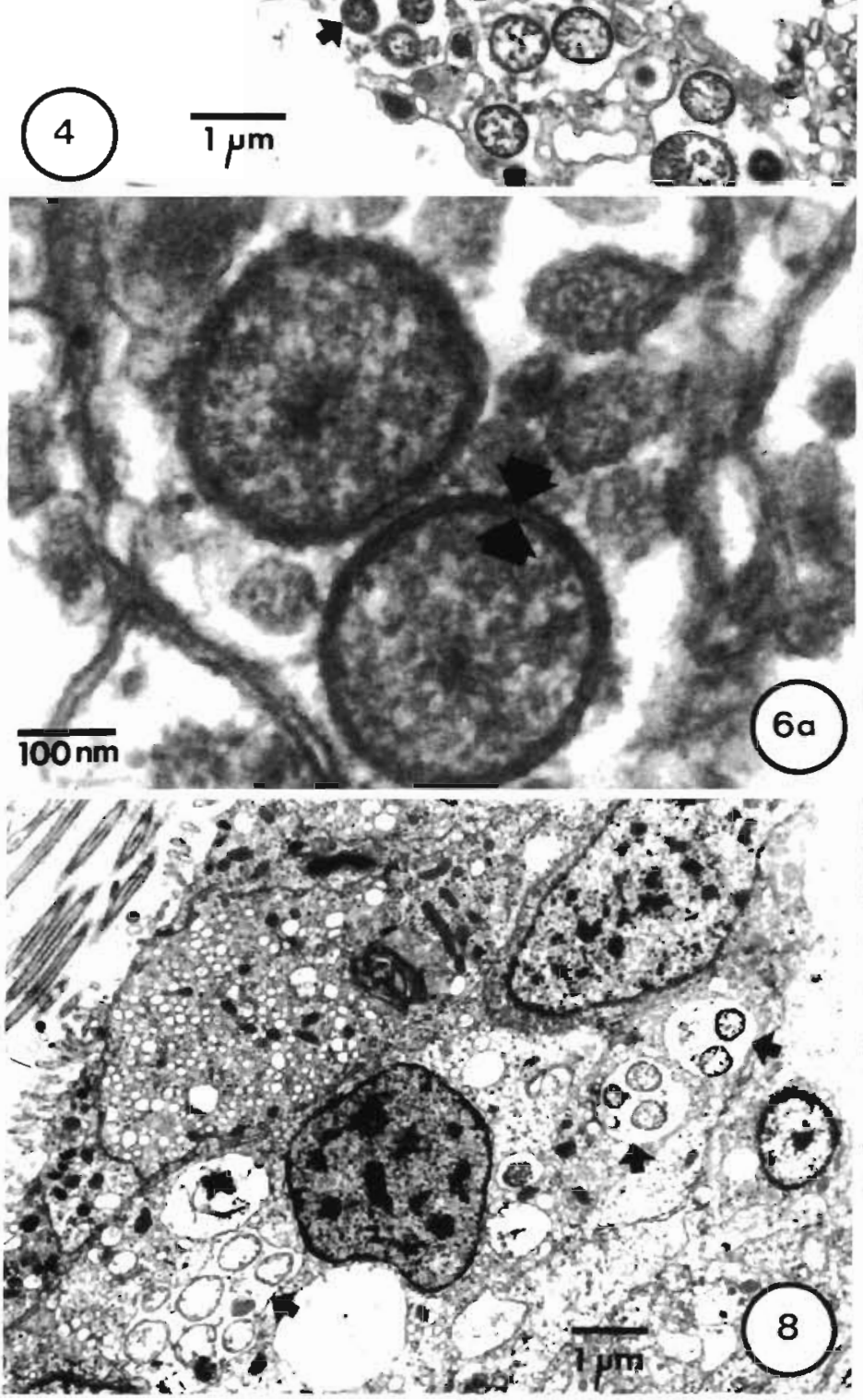

$\operatorname{lom}_{10} x y+\frac{4 x}{200}$ 15.

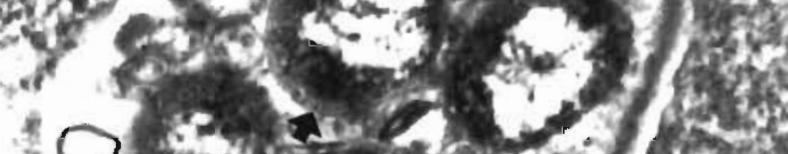
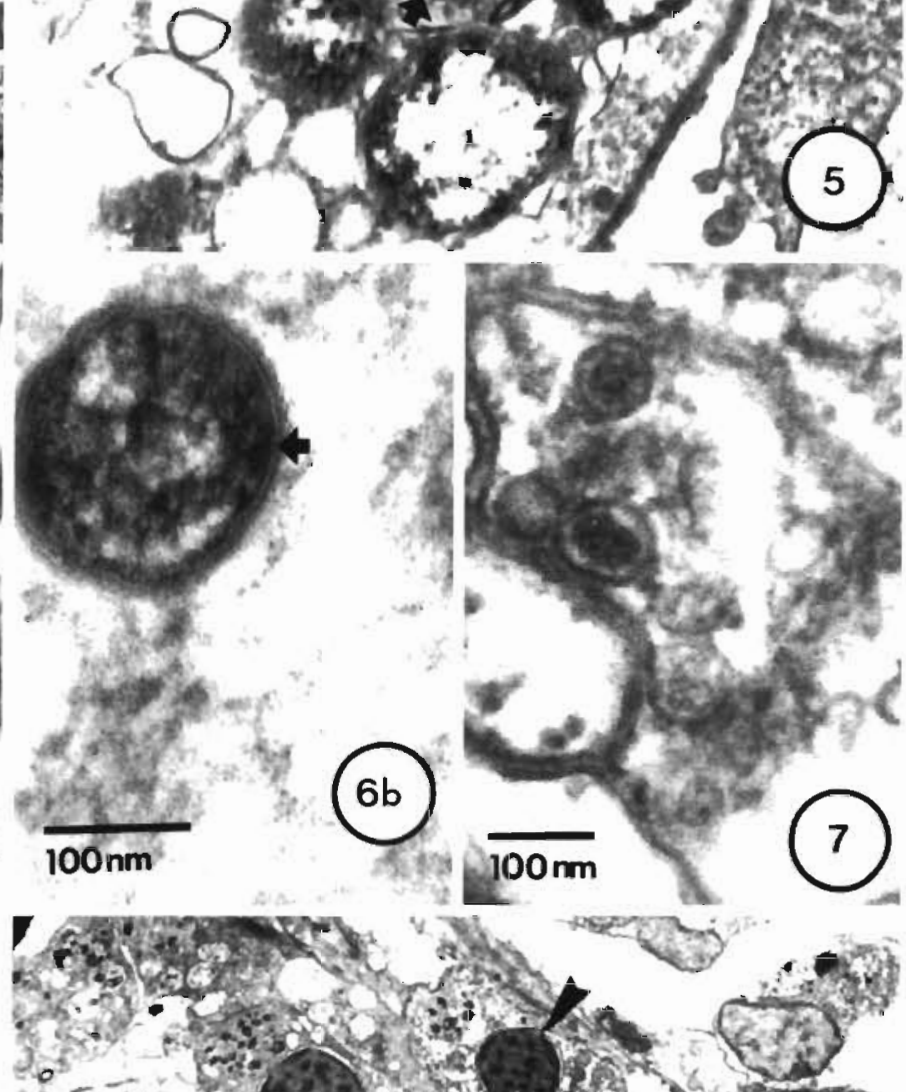

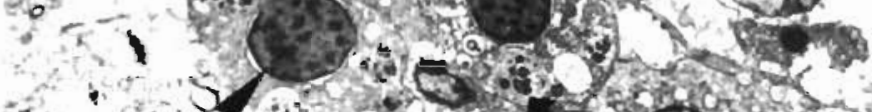

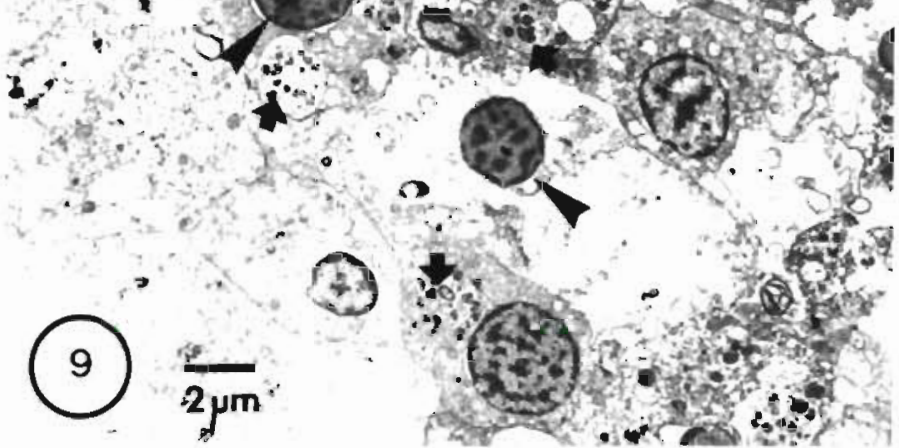

Figs. 4 to 9 Crassostrea gigas. Transmıssion electron micrographs of gill tissues fixed directly in glutaraldehyde or after preservation in Carson's fixative. Fig 4 Individual intracytoplasmic vacuoles containing some intermediate condensing forms and reticulate bodies (arrows). Fig 5 Detall of reticulate bodies in tissues dxrectly fixed in glutaraldehyde Intracytoplasmic reticulate bodies show a clear central area and a penphery fulled with electron dense matenal Note the double membrane (arrows). Fig. 6. Detail of intermediate condensing bodles Note the double membrane around the microorganisms (arrows) Flg 7 Electron dense, round to fusiform elementary bodies. Note the central electron dense region separated from the membrane by an electron transparent space Fig. 8. Intracytoplasmic vacuoles containing chlamydia-like organisms and limited by an inclusion membrane (arrows). Fig. 9. Ultrastructural modifications of cells infected by chlamydialike organisms (arrows) Note pycnotic nucles (arrowheads) and vesiculation of cellular organelles 
$160 \mathrm{~nm}$ (Fig. 7). The central electron dense region was usually separated from the external membrane by an electron lucent space (Fig. F).

Multiplication of the reticulate bodies took place within an expanding membranebound vacuole, or inclusion, an extension in which the parent elementary body was brought into the host cell. However, most of these reticulate bodies were in the nondividing stage and figures indicative of binary fission were rarely observed. An inclusion membrane was observed around oyster procaryotic organism inclusions, separating microorganisms from host cell components until disintegration during the late stages of infection (Fig. 8). Vesicles containing microorganisms varied in size and development.

General vesiculation and eventual lysis of cellular organelles were observable. Mitochondria collected around inclusions and became swollen. Some nuclei were pycnotic (Fig. 9). A consequence of this intense reaction was a drastic change of the normal gill architecture at the affected areas. In addition, fusion of filaments was also observed.

Thin sections of ctenidia and mantle tissue samples of 8 uninfected Japanese oysters from the French Atlantic coast and 10 uninfected oysters originating from Brittany, Normandy and the Mediterranean Sea did not reveal the presence of the microorganism.
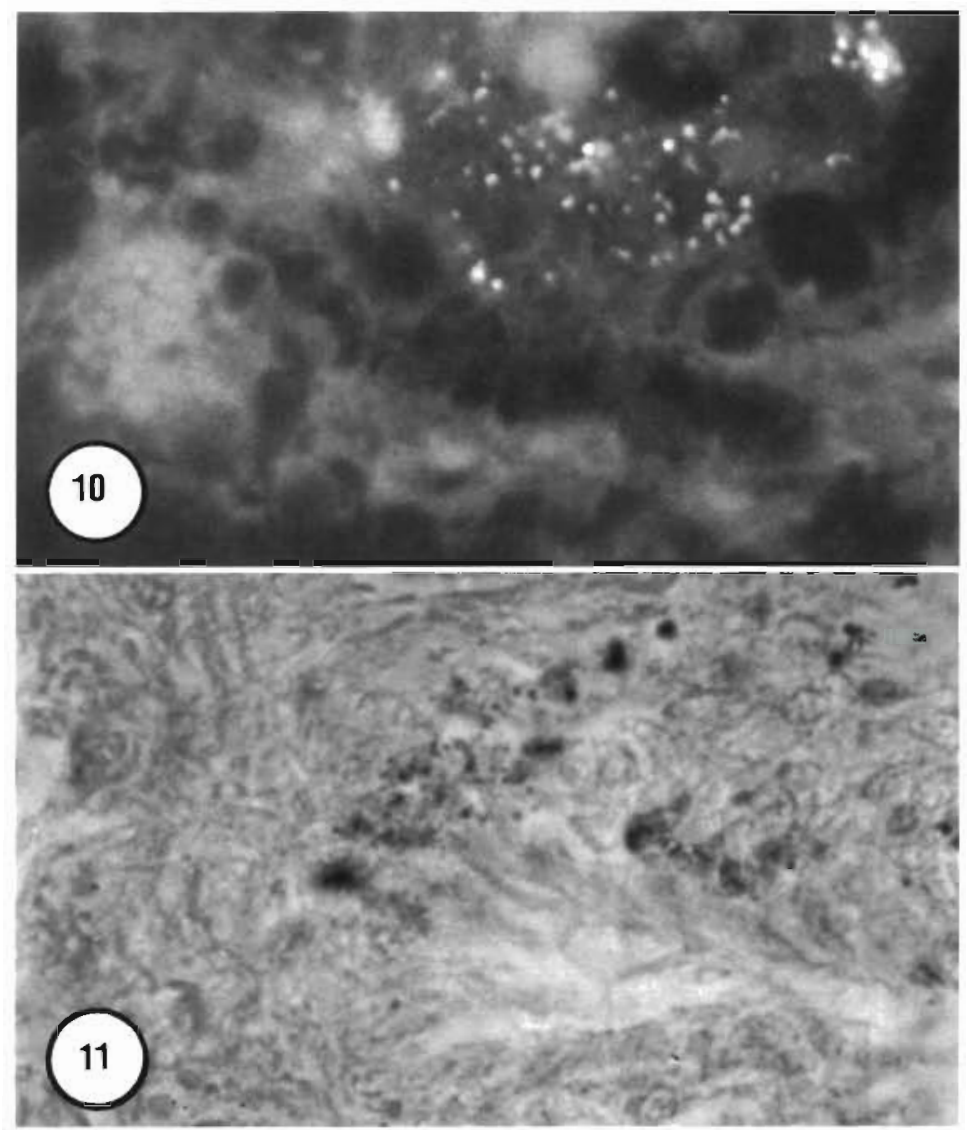

Figs. 10 \& 11. Crassostrea gigas. Fig. 10. Indirect fluorescent monoclonal antibody (AD5A8, 1:1000) test on infected Japanese oyster connective tissues showing specific fluorescence of chlamydia-like organisms. Fig. 11. Indirect immunoperoxidase monoclonal antibody (AD5A8, 1:1000) test on infected Japanese oyster connective tissues showing specific reactivity of chlamydia-like organisms

\section{Indirect immunofluorescence and immunoperoxidase}

Sections of 12 heavily infected oysters, originating from the French Atlantic coast, fixed in Carson's and Davidson's fixatives, were examined by indirect immunofluorescence and immunoperoxidase. With 2 anti-Chlamydia psittaci, strain ovis monoclonal antibodies (AD5A8 and LC1B11), diluted 1:1000 and 1.10000 , all the samples showed specific reactivity within the areas of gill and mantle lesions (Figs. 10 \& 11) for both fixatives. Samples of the 12 fluorescent and peroxidase positive oysters were observed by transmission electron microscopy. Intracellular procaryotic agents were observed in ctenidia and mantle connective tissues in all examined oysters.

For the other anti-Chlamydia psittaci monoclonal antibodies and sheep anti-chlamydial serum, no reactivity was found in ctenidia or mantle of the same heavily infected oysters.

Sections of 8 uninfected Japanese oysters originating from the French Atlantic coast, 10 uninfected animals from Brittany, Normandy and Mediterranean and 20 European flat oysters Ostrea edulis were always negative. No reactivity was observed with anti-Bonamia ostreae monoclonal antibodies on sections of the 12 heavily infected oysters.

Positive controls of cell cultures infected with Chlamydia psittaci, strain ovis always exhibited strong reactivity.

\section{DISCUSSION}

Since the first reports of Harshbarger et al. (1977) and Otto et al. (1979), chlamydia-like procaryotes have been described in various bivalves (see Elston \& Peacock 1984 and Grizel 1987 for reviews).

The presence of reticulate, intermediate and elementary bodies in the ctenidia and mantle connective tissues of the Japanese oyster Crassostrea gigas indicates that the procaryotic agent is more similar to chlamydiales than rickettsiales, which possess a single 
form throughout their life cycle. The different stages of this procaryotic organism appear enclosed within vesicles: the presence of a membrane separating microorganisms from host cell components until disintegration during late stages of infection is compatible with the description for other chlamydial infections (Todd et al. 1976, Ladany \& Sarov 1985, Moulder 1991).

The morphology of the elementary bodies is oval to fusiform as described in other bivalves (Morrison \& Shum 1982, Carajaville \& Angulo 1991). The intermediate condensing forms have similarities with other intermediate bodies reported in mussels (Cajaraville \& Angulo 1991). These chlamydial bodies become further enlarged, vacuolated and transformed into pleomorphic reticulate bodies as described for chlamydia (Higashi et al. 1962, Mitsui et al. 1962, Moulder 1986). Because of the developmental cycle of the microorganism which we have described here, we have identified this procaryotic agent as a chlamydia-like organism.

The presence of DNA has been reported in different stages of micoorganisms belonging to the genus Chlamydia (Starr et al. 1960, Pollard \& Tanami 1962, Moulder 1986). Thus the Feulgen reaction could be useful for distinguishing the chlamydia-like organism inclusions in infected oysters. Moreover, detection of RNA is possible in the different forms of C. psittaci and C. trachomatis, particularly in reticulate bodies (Starr et al. 1960, Pollard \& Tanami 1962, Moulder 1986). In this case, the acridine orange stain could be a good method for detection of these microorganisms. However, in our study, this technique did not give good results because of the $\mathrm{pH}$ of fixatives.

Our study involved formalin-fixed oyster tissue, and the monoclonal antibodies we selected were reactive to the vertebrate pathogen, Chlamydia psittaci, strain ovis. Nevertheless, 2 of these monoclonal antibodies that were specific to lipopolysaccharide antigens (LPS) were cross-reactive with our microorganism. Our method, in which fixed tissues and not frozen sections were used, has been described earlier (Lundmose et al. 1989). If indirect immunofluorescence is carried out with monoclonal antibodies specific to LPS, using Evans blue and powdered milk, high-quality results are obtained. This technique is easily performed; moreover, it can be used to detect microorganisms in old formalin-fixed samples (Lundmose et al. 1989). A specific reactivity with $1: 1000$ and 1:10000 dilutions of the 2 monoclonal antibodies was easily observable, which suggests that our chlamydialike agent might share antigens with C. psittaci, strain ovis, although our microorganism has a greater number of specific characters than the vertebrate chlamydial agents. The lack of reactivity for sheep anti-chlamydial serum and the other 3 monoclonal antibodies could have been due to the destruction of chlamydia-like organism antigens in fixed tissues or to a lack of cross-reactivity.

In contrast to rickettsia-like organisms, which appear in digestive, renal, or branchial epithelium and in connective tissues of bivalves (Meyers 1979, Otto et al. 1979, Morrison \& Shum 1983, Elston \& Peacock 1984, Elston 1986, Villalba et al. 1993), chlamydia-like organisms have been reported only in digestive tissues of bivalves. Thus, our report is the first ultrastructural description of a chlamydia-like organism affecting ctenidia and mantle connective tissues of bivalve molluscs.

Heavy host reactions such as lysis of affecting cells (Morrison \& Shum 1982, Elston \& Peacock 1984), subsequent disappearance of the normal architecture of oysters gill and mantle tissues and hemocyte infiltration of infected areas were observed in the present study. Similarly, ultrastructural alterations were visible in affected ctenidia and mantle cells. Ultrastructural changes were related to the presence of the chlamydia-like organisms in Japanese oyster ctenidia and mantle tissues. General vesiculation and lysis of cellular organelles or swollen mitochondria were apparent. These ultrastructural modifications were best observed in apparent late stages of infection and were compatible with these described for other chlamydial infections (Todd et al. 1976, Moulder 1991). Thus, the chlamydia-like organisms described in this study induce gill and mantle lesions. Although these results are compatible with those described for vertebrate chlamydial infections (Todd et al. 1976, Moulder 1991), in other bivalves infected with chlamydia or rickettsialike organisms, lack of response has often been reported (Meyers 1979, Otto et al. 1979, Joly \& Comps 1980, Elston \& Peacock 1984, Elston 1986, Cajaraville \& Angulo 1991). Lesion intensity and high prevalence of this chlamydia-like organism in oysters from the south French Atlantic coast, associated with occasional mortalities, indicate that this procaryotic agent represents a potential pathogen for the species Crassostrea gigas.

However, study of experimental infection is needed to demonstrate the pathogenicity of this chlamydialike agent. Isolation and purification of this procaryotic agent could also more accurately establish the precise taxonomic status of the microorganism.

Acknowledgements. We thank Prof. Orfila for comments on micrographs, Dr Rodolakis for providing monoclonal antibodies and sheep serum anti-Chlamydia psittaci, strain ovis, and $\mathrm{B}$. Chollet and C. Lipart for technical assistance. The authors also thank $G$. Tigé and $Y$ Pichot for providing histological results about oysters originating from Brittany, Normandy and the Mediterranean Sea. 


\section{LITERATURE CITED}

Azevedo C, Villalba A (1991) Extracellular giant rickettsiae associated with bacteria in the gill of Crassostrea gigas (Mollusca, Bivalvia). J Invertebr Pathol 58:75-81

Buchanan JS (1978) Cytological studies on a new species of rickettsia found in association with a phage in the digestive gland of the marine bivalve mollusc, Tellnna tenuis (da Costa). I Fish Dis 1:27-43

Cajaraville MP, Angulo E (1991) Chlamydia-like organısms in digestive and duct cells of mussels from the basque coast J Invertebr Pathol 58:381-386

Comps M. Bonami JR, Vago C (1977a) Pathologies des invertébrés-Mise en évidence d'une infection rickettsienne chez les huitres. C r Acad Sci, Paris 285:427-429

Comps M, Deltreil J (1979) Un microorganisme de type rickettsien chez l'huitre portugaise Crassostrea angulata Lamarck. C r Acad Sci, Paris 289:169-171

Comps M. Tigé G, Duthoit J, Grizel H (1977b) Microorganisme de type rickettsien chez les huitres Crassostrea gigas et Ostrea edulis. Haliotis 8:317-321

Couch JA (1985) Prospective study of infectious and noninfectious diseases in oysters and fishes in three Gulf of Mexico estuaries. Dis aquat Org 1:59-82

Culling CFA (1974) Handbook of histopathological and histochemical techniques, 3rd edn. Butterworths, London

Elston RA (1986) Occurrence of branchial rickettsiales-like infections in two bivalve molluscs, Tapes japonica and Patenopecten yessoensis, with comments on their significance. J Fish Dis 9:63-71

Elston RA, Peacock MG (1984) A rickettsiales-like infection in the razor clam, Siliqua patula. J Invertebr Pathol 44: $84-96$

Fries GR, Gram SB, Tripp MR (1991) Rickettsiose in the cytoplasm of gill epithelial cells of soft-shelled clam, Mya arenaria. J Invertebr Pathol 5:443-445

Grizel H (1987) Les maladies des mollusques: étiologie et progrès récents des recherches. Océanis $13: 357-370$

Gulka G. Chang PW, Marti KA (1983) Procaryotic infection associated with a mass mortality of the sea scallop Platopecten magellanicus. J Fish Dis 6:355-364

Harshbarger JC, Chang SC, Otto SV (1977) Chlamydia (with phages), mycoplasmas and rickettsiae in Chesapeake Bay bivalves. Science 196:666-668

Higashi N, Tamura A. Iwanaga M (1962) Developmental cycle and reproductive mechanism of the meningopneumonitus virus in strain L cells. In: Gordon FB (ed) The biology of the trachoma agent. Annls NY Acad Sci 98:100-121

Joly JP, Comps H (1980) Etude d'un microorganisme de type chlamydien chez la palour de Ruditapes decussatus L. Rev Trav Inst Pêches marit 44:285-287

Ladany S, Sarov I (1985) Recent advances in Chlamydia trachomatis. Eur J Epidemiol 1:235-256

Responsible Subject Editor: A. K. Sparks, Seattle, Washington, USA
Le Gall G, Chagot D, Mialhe E, Grizel H (1988) Branchial rickettsial-like infection associated with a mass mortality of sea scallop Pecten maximus. Dis aquat Org 4: $229-232$

Leibovitz L (1989) Chamydiosis: a newly reported serious disease of larval and postmetamorphic bay scallop, Argopecten irradians (Lamarck). J Fish Dis 12:125-136

Lundmose $A G$, Lundmose JB, Birkelund S, Christiansen G (1989) Detection of Chlamydia in postmortem formalinfixed tissue. APMIS 97:68-74

Meyers TR (1979) Preliminary studies on a chlamydial agent in the digestive diverticular epithelium of hard clam Mercenaria mercenaria (L) from Great South Bay, New York. J Fish Dis 2:179-189

Mitsui Y, Kajima M. Nishimura A, Konishi K (1962) Morphology of trachoma agent in conjunctive and chick embryo. In: Gordon FB (ed) The biology of the trachoma agent. Annls NY Acad Sci 98:131-144

Morrison CM, Shum G (1982) Chlamydia-like organisms in the digestive diverticule of the bay scallop. Argopecten irradians (L). J Fish Dis 5:173-184

Morrison CM. Shum G (1983) Rickettsias in the kidney of the bay scallop, Argopecten irradians (Lamarck). J Fish Dis 6:537-541

Moulder JW (1986) The Rickettsias and Chlamydias. Order II. Chlamydiales. In: Sneath PVR, Main NS, Sharp ME, Halt JG (eds) Bergey's manual of systematic bacteriology, Vol I. Williams \& Wilkins, Baltimore, p 729-739

Moulder JW (1991) Interaction of chlamydiae and host cells in vitro. Microbiol Rev 55:143-190

Norton JH, Shepherd MA, Abdon-Naguit MR, Linsday S (1993) Mortalities in the giant clam Hippopus hippopus asssociated with Rickettsiales-like organisms. J Invertebr Pathol 62:207-209

Otto SV, Harshbarger JC, Chang SC (1979) Status of selected unicellular eucaryote pathogens and prevalence and histopathology of inclusions containing obligate procaryote parasites in commercial bivalve molluscs from Maryland estuaries. Haliotis 8:285-295

Pollard $M$, Tanami $Y$ (1962) Cytochemistry of trachoma virus in tissue cultures. In: Gordon FB (ed) The biology of the trachoma agent. Annls NY Acad Sci 98:50-61

Starr TJ, Pollard M, Tanami Y, Moore RW (1960) Cytochemical studies with psittacosis virus by fluorescence microscopy. Texas Rep Biol Med 18:501-507

Todd WJ, Doughri AN, Storz J (1976) Ultrastructural changes in host cellular organelles in the course of the chlamydial development cycle. Zbl Bakt ParasitenKde, 1 Abt, Originals (Reihe A) 236:359-373

Villalba A, Azevedo C, Rodriguez C (1993) Occurrence of multiple hyperplasic growths on the gills of Pacific oyster, Crassostrea gigas, and their relationship with associated pathologic conditions. J Invertebr Pathol 61:296-302

Manuscript first received: January 3, 1994

Revised version accepted: June 6,1995 